\title{
Article
}

\section{Human Rights, Positive Obligations, and Measures to Prevent Human Trafficking in the UK}

Turner, Ian David

Available at http://clok.uclan.ac.uk/12600/

Turner, Ian David ORCID: 0000-0002-8012-1480 (2015) Human Rights, Positive Obligations, and Measures to Prevent Human Trafficking in the UK. Journal of Human Trafficking, 1 (4). pp. 296-317. ISSN 2332-2705

It is advisable to refer to the publisher's version if you intend to cite from the work. http://dx.doi.org/10.1080/23322705.2015.1034612

For more information about UCLan's research in this area go to http://www.uclan.ac.uk/researchgroups/ and search for < name of research Group>.

For information about Research generally at UCLan please go to http://www.uclan.ac.uk/research/

All outputs in CLoK are protected by Intellectual Property Rights law, including Copyright law. Copyright, IPR and Moral Rights for the works on this site are retained by the individual authors and/or other copyright owners. Terms and conditions for use of this material are defined in the policies page.

\section{CLoK}

Central Lancashire online Knowledge www.clok.uclan.ac.uk

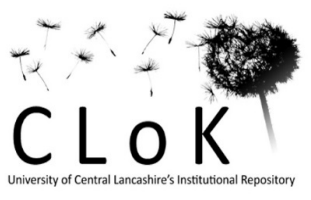


HUMAN RIGHTS, POSITIVE OBLIGATIONS AND MEASURES TO PREVENT

HUMAN TRAFFICKING IN THE UK

\begin{abstract}
Article 4 of the European Convention on Human Rights is freedom from slavery. A key feature of this right is the obligation it imposes on states such as the UK to prevent violations of the freedom, such as the trafficking in human beings, by third parties. This piece finds that the UK's response to its duties in preventing human trafficking is patchy but concludes that this will be much improved with its new Modern Slavery Bill 2014-15.
\end{abstract}

\title{
Keywords
}

Human rights; freedom from slavery; positive obligations; human trafficking 


\section{Introduction}

Slavery and the trade in slaves are prohibited by the international Slavery Convention, signed in 1926. Article 2 of the Convention obliges state parties: (a) to prevent and suppress the slave trade; and (b) to bring about, progressively and as soon as possible, the complete abolition of slavery in all its forms. Article 1 of the Convention defines 'slavery' as: ‘the status or condition of a person over whom any or all of the powers attaching to the right of ownership are exercised'. International protection against slavery and the slave trade was strengthened in 1956: Supplementary Convention on the Abolition of Slavery, the Slave Trade, and Institutions and Practices Similar to Slavery. This Convention also outlawed 'practices similar to slavery’. According to Article 1 these practices can include 'debt bondage' - 'the status or condition arising from a pledge by a debtor of his personal services...as security for a debt, if the value of those services...is not applied towards the liquidation of the debt...' - and 'serfdom' - 'the condition or status of a tenant who is...bound to live and labour on land belonging to another person and to render some determinate service to such other person, whether for reward or not, and is not free to change his status.'

Article 5 of the 1926 Convention also obliges state parties to take all necessary measures to prevent conditions such as compulsory or forced labour from developing into situations analogous to slavery. That said, there are international conventions enhancing the protection of individuals who find themselves in conditions of forced or 
compulsory labour: the International Labour Organisation's (ILO) Convention Concerning Forced or Compulsory Labour (No.29), 1930 and Convention Concerning the Abolition of Forced Labour (No.105), 1957, for example. Article 2(1) of the 1930 Convention defines forced or compulsory labour. These practices contain three main elements: first, some form of work or service must be provided; second, the work is performed under the threat of a penalty, which can be for example physical, psychological or financial; and third, the work is undertaken involuntarily, meaning that the person either became engaged in the activity against their free will or, once engaged, finds that they cannot leave the job.

Trading in slaves was abolished in Britain by the Slave Trade Act 1807. This was more than 200 years ago. But slavery still persists. The definition of slavery in the 1926 Convention, as stated above, focuses on the notion of 'ownership', the idea that a person can be bought and sold. But, nowadays, the element of ownership, or rather 'powers attached to the right of ownership', no longer require the trade of a person for money or some other value - see, for example, the ruling of the International Criminal Tribunal for the former Yugoslavia (ICTY) in Prosecutor v. Kunarc, Case no. IT-96-23-T. There, the court said that slavery was indicated by, say, the restriction or control of an individual's autonomy, freedom of choice or freedom of movement; and, often, the accruing of some gain to the perpetrator. The consent or free will of the victim was absent. Further indications of enslavement included exploitation; the exaction of forced or compulsory labour or service, often without remuneration and often, though not necessarily, involving physical hardship. Thus, the reach of 'modern' slavery is very broad: it is not confined to the term as 
traditionally used in the 1926 Convention and can include practices of 'debt bondage' and 'serfdom', as well as others involving 'forced' and 'compulsory' labour.

'Modern' slavery came to particular attention to the minds of the British people a couple of months ago (at the time of writing), when three women, who were thought to have been held as slaves for more than 30 years in south London, were set free. The three women released - a 69-year-old from Malaysia, a 57-year-old from Ireland and a 30-year-old from Britain, who was believed to have spent her entire life in detention - were treated as household slaves and only allowed to go out to put out washing or go shopping under the close supervision of their captors. Experts claimed that it could be the most enduring case of modern-day slavery in the UK (Milmo, 2013). And only yesterday (at the time of writing) a man was liberated after having been held in captivity for 24 years: he was allegedly brought to Britain in 1989 and moved around various addresses in England for the purposes of exploitation (Press Association, 2014). But these incidents are not unusual, in the UK or abroad.

The ILO published its first global estimate of modern slavery in 2005. It estimated that in the period 1995-2004 over 12 million people worldwide were held in some form of modern slavery. In 2012 the ILO revised this estimate, believing for the period 2002-2011 the number was nearly 21 million (International Labour Organisation, 2012). More recently, researchers have calculated what is known in criminal statistics as the 'dark figure' for modern slavery. A dark figure is the difference between the number of incidences of a crime that are reported and recorded 
officially and the actual and true amount of that crime in society (Datta \& Bales, 2013). The latest figures, which measure the scale of the problem on a country-bycountry basis, estimate that about 36 million people worldwide are living in modern slavery. The index ranks 167 countries and identifies risk factors for enslavement and the government responses. The results suggest that there are more than 500,000 people held in slavery in Europe, of which there are more than 8,000 in the UK (Walk Free Foundation, 2014).

Freedom from slavery is also protected under international human rights law: Article 4 of the Universal Declaration on Human Rights and Article 8 of the International Covenant on Civil and Political Rights, for example. Regional human rights law such as Article 5 of the African Charter of Human and Peoples' Rights, Article 6 of the American Convention on Human Rights, Article 10 of the Arab Charter on Human Rights, Article 4 of the European Convention on Human Rights (ECHR) and Article 5 of the Charter of Fundamental Rights of the European Union, protect the freedom, too.

Ordinarily, human rights like freedom from slavery act 'negatively'. That is, they prevent interferences by the state with the liberties of the individual; they are ‘freedoms from’ state intrusion. But this right, for example, does not sit easily with traditional 'negative', human rights law. Unlike slavery in the historical sense of legal ownership of a person, this form of abuse is now primarily carried out by powerful private criminal organisations (Drew, 2009). A typical feature of fundamental rights 
like freedom from slavery, therefore, is that they also impose 'positive' or 'substantive' obligations on a state, meaning that a state may be in violation of the right where it has forseen, or at the very least should have forseen, a serious risk of harm to a particular individual by a third party and not acted reasonably in averting it, as per, say, the ruling of the European Court of Human Rights (ECtHR) in Siliadin v. France [2001] ECHR 73316/01.

Trafficking in human beings is considered a form of modern slavery. The 'positive' or 'substantive' human rights obligations imposed on a state to prevent slavery by third parties also apply to human trafficking: the ruling of ECtHR in Rantsev v. Cyprus and Russia [2010] ECHR 25965/04, for example. In 2006, the UK’s Parliamentary Joint Committee on Human Rights (JCHR) said that the then level of protection provided to victims of human trafficking in Britain was 'far from adequate' and needed to be put on a 'far more reliable basis to meet its human rights obligations'. One way to achieve this was to ensure that the enforcement of the law must always make the interests and needs of victims a primary consideration, to prevent them from, say, being re-trafficked (Parliamentary Joint Committee on Human Rights, 2006). A question to be asked, therefore, is the UK still not meeting its 'positive' human rights responsibilities some ten years later? In the time since the publication of the JCHR report, in 2006, the country ratified, for example, the Council of Europe's (CoE) Convention on Action Against Trafficking in Human Beings, in 2008. Indeed, the UK government has recently published a Modern Slavery Bill, much of which will apply to the whole of Britain (Scotland is partly excluded but any gaps there will be filled by the Human Trafficking (Scotland) Bill). The aims of the 
Modern Slavery Bill include: consolidating into a single act the UK's trafficking offences, as well as increasing the maximum sentence from 14 years to life imprisonment. The UK's Home Secretary, Theresa May, has said that this 'flagship Bill' will be the first of its kind in Europe, sending a strong message, both domestically and internationally, that the UK is determined to put an end to modern slavery (Home Office, 2013a). This is a grand statement by the Home Secretary but with respect what effect will the proposals have in practice, if at all? Assessing whether the UK does comply, or will comply, with its positive duties under human rights law to prevent trafficking is therefore the purpose of this article. But first it is important to discuss human trafficking, and especially its corresponding duties imposed on the UK, which is the aim of the next section.

\section{UK obligations to prevent human trafficking}

According to Article 3(a) of the United Nations Protocol to Prevent, Suppress and Punish Trafficking in Persons, Especially Women and Children ('UN Protocol'), the constituent elements of human trafficking include: the recruitment, transportation, transfer, harbouring or receipt of persons, by means of the threat or use of force or other forms of coercion, of abduction, of fraud, of deception, of the abuse of power or of a position of vulnerability, for the purpose of exploitation. Exploitation involves, say, the prostitution of others or other forms of sexual exploitation, forced labour or services, servitude or the removal of organs. There are therefore three key parts to human trafficking: a movement; a control; and a purpose 
such as the sexual or labour exploitation of a person. Human trafficking is commonly viewed as a transnational crime but the movement of a person can also be internal (Brayley and Cockbain, 2014).

Human trafficking is regarded as a contemporary form of slavery (Drew, 2002; Scarpa, 2008), especially by those who liken the practice to, say, historical efforts to prevent the cross border movement of mostly European, white women for the purposes of prostitution ('white traffic'), such as the International Convention for the Suppression of the 'White Slave Traffic' in 1910, as well as broader measures to prevent the trafficking of all women for the purposes of prostitution, such as the International Convention for the Suppression of the Traffic in Women of Full Age in 1933 (Pati, 2011). But unlike, say, holding a person in slavery, which is a separate criminal offence to human trafficking in the UK, as per s.71 of the Coroners and Justice Act 2009 (though this does not apply to Scotland which has its own legislation: the Criminal Justice and Licensing (Scotland) Act 2010), trafficking also involves the movement of a person, thus furthering the isolation of a victim and strengthening an abuser's control over them (Piotrowicz, 2012).

States such as the UK must adopt positive measures to deter human trafficking. In 2002 the United Nations High Commissioner for Human Rights published the Recommended Principles and Guidelines on Human Rights and Human Trafficking. Its core principles emphasise: 'preventing trafficking' (principles 4-6); 'protection and assistance' to victims (principles 7-11); and 'criminalization, 
punishment and redress' (principles 12-17). Internationally, therefore, human rights principles informing states' anti-trafficking measures should - 'prevent' and 'protect', as well as 'criminalize', or 'prosecute', to give the principles their short-title of the '3Ps’. Often 'positive’ state obligations under human rights law such as those attached to freedom from slavery are couched in terms of 'prevent', but fulfilling this duty can be achieved in several ways; in reference to, say, the UN Protocol, which the UK ratified in 2006, Article 5 obliges state parties to criminalise human trafficking. A state's emphasis upon the 'prosecution' of those who engage in human trafficking can therefore contribute to 'preventing' (or at the very least reducing) future harm against a person because of, say, its deterrent effect. 'Prevention' can also be achieved through 'protection': the UN Protocol obliges state parties to provide assistance to and protection of victims of trafficking, as per Article 6; and Article 7 encourages states to allow victims of trafficking to remain in their country of transit, temporarily or permanently, if they so wish. Thus, by encouraging victims to come forward by offering assistance, and in some cases permitting them to stay, Articles 6 and 7 can 'prevent' the continuance of the harm. Article 9 of the UN Protocol, which is expressly referred to as 'Prevention of trafficking in persons', requires state parties to establish comprehensive policies, programmes and other measures: (a) to prevent and combat trafficking in persons; and (b) to protect victims of trafficking in persons from revictimization. Furthermore, Article 9 states that state parties should take measures to alleviate the factors that make people vulnerable to trafficking, such as poverty, underdevelopment and lack of equal opportunity, as well as discourage the demand that leads to trafficking. 
There are also European human rights laws requiring states to 'prevent' human trafficking. In Rantsev, for example, the victim had been trafficked from Russia to Cyprus for reasons of sexual exploitation. In the interpretation of Article 4 of the ECHR, the freedom from slavery, the ECtHR ruled that there had been a violation of the right; in particular, Cyprus had failed in its positive duty to protect the victim from being trafficked. In discussing European states' substantive duties to prevent trafficking, the ECtHR said that countries (such as the UK which ratified the ECHR in 1951) must: (1) adopt criminal law measures to punish traffickers; (2) put in place appropriate legal and administrative frameworks to prevent people becoming victims of trafficking; (3) take protective operational measures when it is demonstrated that the State authorities were aware, or ought to have been aware, of circumstances giving rise to a credible suspicion that an identified individual has been, or was at real and immediate risk of being, trafficked or exploited; and (4) cooperate in cross-border trafficking cases. Moreover, the court also confirmed that there was a secondary, procedural duty imposed on European states, arising from their positive obligations, to investigate credible allegations of trafficking. (But there are some who disagree with the ruling of the ECtHR in Rantsev that human trafficking is a violation of Article 4 (Stoyanova, 2012), thus, there are some who question whether indeed human trafficking is slavery (Obokata, 2006; van der Wilt, 2014).)

In addition, there are European instruments dedicated specifically to outlawing trafficking such as the CoE's Convention on Action Against Trafficking in Human Beings, which the UK ratified in 2008. Article 4(a) of the CoE Convention adopts the same definition of trafficking as Article 3(a) of the UN Protocol; and Articles 5 and 6 
of the CoE Convention, which are described as 'Prevention of trafficking in human beings' and 'Measures to discourage the demand' respectively, are similar in nature to Article 9 of the UN Protocol. Like Article 5 of the UN Protocol, Article 18 of the CoE Convention also imposes obligations on state parties to criminalise trafficking in humans, which according to Article 23(1), must be 'punishable by effective, proportionate and dissuasive sanctions'. The UN Protocol is silent, however, on important issues such as 1) the identification of victims 2) the status of the victim who commits a trafficking-related offence and 3) a national monitoring system, unlike the CoE Convention (Mattar, 2008). In reference to point 1, for example, Article 10(1) of the CoE Convention states that parties shall provide its competent authorities with persons who are trained and qualified in preventing and combating trafficking in human beings, in identifying and helping victims. Such a procedure, according to Article 10(2), establishes that, if the competent authorities have reasonable grounds to believe that a person has been a victim of trafficking, that person shall not be removed from its territory until the identification process has been completed. Article 12 is concerned with the assistance to victims. Following on from Article 10, Article 13 introduces a recovery and reflection period, of at least 30 days, when there are reasonable grounds to believe that the person concerned is a victim of human trafficking. Such a period shall be sufficient for the person concerned to recover and escape the influence of traffickers and/or to take an informed decision on cooperating with the competent authorities. During this period it shall not be possible to enforce any expulsion order against them. 
Article 26 of the CoE Convention, which is labelled as a 'non-punishment provision', recommends not imposing penalties on victims for their involvement in unlawful activities, to the extent that they have been compelled to do so. In terms of monitoring states' compliance with the CoE Convention, Article 29 suggests that each party shall consider appointing National Rapporteurs or equivalent for monitoring the anti-trafficking activities of State institutions and the implementation of national legislation requirements; and Article 36 creates a Group of Experts on Action Against Trafficking in Human Beings (GRETA). GRETA is composed of 15 independent and impartial experts chosen for their recognised competence in the fields of human rights, assistance and protection of victims, and action against trafficking in human beings (Group of Experts on Action Against Trafficking in Human Beings, 2012).

Regionally, in Europe, there is also Article 5(3) of the Charter of Fundamental Rights of the European Union, prohibiting human trafficking. (The UK originally negotiated an opt-out from this Charter, but some argue that it now binds the country following, say, the ruling of the European Court of Justice (ECJ) in C-176/12 Association de Médiation Sociale v. Union Locale des Syndicats CGT (Young, 2014).) The European Union (EU), which is a separate regional body to the CoE, though all members of the EU are members of the CoE, but not vice versa, has also issued a Directive on trafficking: Preventing and Combating Trafficking in Human Beings and Protecting its Victims, which the UK also ratified in 2008. As per Article 11 of the EU Directive, for example, the definition of human trafficking is slightly broader than that contained in the UN Protocol and the CoE Convention, in that it includes additional forms of exploitation such as begging. Article 7 of the Directive 
claims to adopt an integrated, holistic, and human rights approach to the fight against trafficking in human beings and seeks to build on existing regional initiatives. Article 14 suggests how this approach may be achieved: safeguarding victims, avoiding further victimisation and encouraging them to act as witnesses in criminal proceedings against their perpetrators.

\section{Human trafficking in the UK}

Article 29 of the CoE Convention encourages the establishment of national rapporteurs or equivalent mechanisms to monitor the implementation of domestic anti-trafficking measures and to advise governments on trafficking issues. In the UK this role is undertaken by the Inter-Departmental Ministerial Group on Human Trafficking whose duty is to: assess trends in human trafficking; coordinate and measure results of anti-trafficking actions and to report to Parliament (Gov.UK, 2013). The group published its first annual assessment of human trafficking in the UK in October 2012 (HM Government, 2012) and its second one in October 2013 (HM Government, 2013). (The group published a third report in October 2014, which was 'a short, action-focused update'. Because of the 'significant volume of activities ongoing', the group claimed that a more comprehensive report was planned for next year (HM Government, 2014).) A key outcome from the first and second reports was 'improving our response'. In its first report the group said that the UK had strengthened governance arrangements to better support coordination of human trafficking work in the UK. The country was also taking work forward with a range of 
other government departments to strengthen prevention activities by working with a range of key stakeholders, in the UK and overseas. And three key areas were identified where further concerted effort was needed to improve and strengthen the UK's approach: data capture and intelligence sharing; training and awareness raising for front-line professionals; and coordinating prevention activities (HM Government, 2012).

The UK also seeks to discharge its positive, human rights obligations by publishing an anti-trafficking strategy, which it did for the first time in 2007: UK Action Plan on Tackling Human Trafficking. In it the government pledged to make human trafficking a part of core police business; detect and identify victims; provide more support and rights for all adult victims; and provide specific measures to safeguard and protect child victims. Another strategy, Human Trafficking: the Government's Strategy, which was published in 2011, covered the period 2011-15. There, the government pledged, for example, to make the process of identifying victims of trafficking, the National Referral Mechanism (NRM), more accessible by enabling more organisations to refer individuals to it and raise awareness of trafficking among front line staff (HM Government, 2011). Since 2011, the UK government has published two further strategies: its Serious and Organised Crime Strategy, where it undertook to improve support for victims of human trafficking, both in the UK and those returning home (Home Office, 2013b); and more recently its Modern Slavery Strategy (HM Government, 2014b). Interestingly, the latter strategy emphasises a '4P' approach to tacking slavery in Britain: 'prevent' and 'protect', as 
well as a new 'P', 'prepare' ('prepare better for when these crimes do take place'), and 'pursue', which replaces 'prosecute'.

The UK appears 'to talk the talk' when it comes to efforts at national level to prevent trafficking, but how prevalent is human trafficking in the UK? In 2011 the first official assessment of human trafficking in the country was published, revealing that there had been 2,077 suspected victims of human trafficking in 2010 (Doward, 2012). The latest figures published in 2015, for 2014, identify 2340 suspected victims of human trafficking. $71 \%$ of suspected victims were adults and $29 \%$ were children. $61 \%$ of suspected adult victims were female and $39 \%$ were male. Suspected adult victims were from 96 different countries of origin. Sexual exploitation - 41\% of suspected victims - and labour exploitation - $27 \%$ of suspected victims - were the two most common exploitation types for adults. A further $9 \%$ of suspected adult victims were subjected to criminal exploitation and $8 \%$ were subjected to domestic servitude (the most common type for children was labour exploitation). The five most common countries of origin of suspected adult victims were Albania, Nigeria, Vietnam, Romania and Poland. The five most common countries of origin of suspected child victims were Albania, Vietnam, the UK, Slovakia and Nigeria (National Crime Agency, 2015).

But many treat official statistics on human trafficking, not just those of the UK, with some scepticism (Gallagher, 2014), because of, say, the poor quality of data collection (Lee, 2007) and the systems for defining victims (Chaudary, 2011). 
Moreover, many victims are too frightened to report their abuse: they could be worried about their immigration status, anxious about exposing themselves to criminal charges, fearful of reprisals from their abusers and/or just simply being too traumatised by the experience to cooperate with the authorities (Bowcott \& Laville, 2013). Criminal convictions for enslavers are generally low, thus some victims see little incentive in coming forward, suspecting that traffickers can act with relative impunity. And finally there are simply some individuals who do not even believe they have been victims of a crime (Home Office, 2013a). According to the Walk Free Global Survey Index 2014, 8,300 people are estimated to be held in slavery in the UK, though this figure accounts for all forms of modern slavery, not just those that have been trafficked. Nevertheless, it is likely that the number of suspected victims of trafficking in the UK is much higher than the official figure of over 2,300. That said, Walk Free suggests that if there are about 65 million people in the UK, then about 0.013 of the total population are held in slavery. The organisation ranks countries in the world by prevalence of population in slavery, concluding that the UK ranks 149 out of 167 countries (the higher the number, the less severe the problem) (Walk Free Foundation, 2014). On the face of it, therefore, British attempts to prevent modern slavery, including human trafficking, or to make the country less attractive to those who wish to engage in the practice, seem to be working, at least when compared to most other countries in the world. Whether this is so, and whether the UK is indeed complying with its duties under human rights law, will be explored in the next section. 


\section{Assessing the UK's compliance with its obligations to prevent trafficking}

The UK has a positive duty to prevent human trafficking, as per Rantsev, for example, by putting in place effective legislative and administrative measures to discourage the practice. It will be recalled that effective 'prevention' can involve the 'prosecution' of those suspected of trafficking, as per, say, Article 18 of the CoE Convention, otherwise there is little incentive on criminals to desist from the crime. For example, the Sexual Offences Act 2003 criminalises trafficking into the UK, within the UK, and out of the UK for the purposes of sexual exploitation: ss.57-59 respectively (which excludes Scotland, as it has its own legislation: the Criminal Justice (Scotland) Act 2003). And, assuming a person arranges or facilitates the arrival into the UK of an individual, the Asylum and Immigration (Treatment of Claimants, etc.) Act 2004 criminalises trafficking into the UK, within the UK, and out of the UK - ss.4(1), 4(2) and 4(3) respectively - for reasons other than sexual abuse such as exploitation for labour, organ removal or benefit fraud. More recently, the UK has outlawed human trafficking committed by British nationals anywhere in the world and human trafficking for purposes of non-sexual exploitation which has taken place wholly within the UK, as per ss. 109 and 110 of the Protection of Freedoms Act 2012 respectively. The maximum sentence for human trafficking in the UK is 14 years imprisonment. These statutes, as well as the maximum sentences, suggest that the country is seemingly complying with, say, its 'prosecute' responsibilities in the CoE Convention (though the number of convictions and the terms of imprisonment in the UK could be higher (Turner, 2014) and there are practical problems in directly importing trafficking definitions from international and regional human rights 
instruments such as the CoE Convention into domestic criminal law (Stoyanova, 2014).)

The UK's substantive, preventative obligation also extends to the 'protection' of victims such as their effective identification, so that they can be removed from harm and given access to services to support them. Inadequate protection undermines prevention as it increases the risk of retrafficking. One way the UK seeks to discharge its human rights obligations in protecting victims of human trafficking is through the NRM. This is a framework for identifying '[potential] victims of human trafficking' (PVoT) and ensuring they receive the appropriate protection and support. It is also the mechanism through which data about victims is collected. To be referred to the NRM, a PVoT must first be referred to one of the UK's two competent authorities (CAs). This initial referral will generally be handled by an authorised agency such as a police force. The referring authority is known as the 'first responder'. In the UK the two CAs are the UK Human Trafficking Centre (UKHTC), which deals with referrals from the police, local authorities, and NGOs, and UK Visas and Immigration (UKVI), which deals with referrals identified as part of the immigration process (National Crime Agency, 2014). It will be recalled that Article 10(2) of the CoE Convention sets out a process for identifying a PVoT: '...if the competent authorities have reasonable grounds to believe that a person has been victim of trafficking in human beings, that person shall not be removed from its territory until the identification process as victim has been completed.' The 'reasonable grounds' test is a CA's first stage of identifying a PVoT. If there is a positive finding once the first stage has been completed, the PVoT will then be provided accommodation within a Government 
funded safe house, if required, and granted a recovery and reflection period of 45 days. During this 45 day period the CA gathers further information relating to the referral from the first responder and other agencies. This additional information is used to make a 'conclusive decision' on whether the referred person was in fact a victim of human trafficking. This is the second stage test and completes the identification process. If the referred person is conclusively identified as having been a victim of trafficking, they may then be granted discretionary leave to remain in the UK for one year, which can be extended if required (National Crime Agency, 2014). In reference to statistics, 946 people were referred to the NRM in 2011 and 1186 in 2012. Of these, 658 received a positive conclusive decision and were adjudged to have been trafficked in 2011 and 778 in 2012 (UK Human Trafficking Centre, 2013). More recent figures state that there were 1746 referrals to the NRM in 2013 (the numbers of those who were adjudged to have been conclusively trafficked in 2013 are still being processed) (National Crime Agency, 2014).

The trend in the UK is an annual increase in NRM referrals, as well as positive conclusion decisions. The increase may indicate improved victim identification, and a greater confidence on the part of potential victims to come forward and cooperate with law enforcement agencies (UK Human Trafficking Centre, 2013). But as explained earlier many treat official statistics on human trafficking with scepticism. In the case of the NRM, some argue that the numbers should be far higher, suggesting that in fact the system is failing to identify, and therefore protect, many hundreds of other trafficking victims. The Anti-Trafficking Monitoring Group (ATMG), a coalition of nine UK based organisations, which was set up in 2009 to monitor the 
UK’s implementation and compliance with the CoE Convention, published a damning report of the country's treatment of victims in 2010: Wrong Kind of Victim? One Year on: an Analysis of UK Measures to Protect Trafficked Persons. The report severely criticised the NRM, arguing that the referral process was 'flawed'. In explaining why, the report said that the number of referrals had not been a true reflection of the extent of trafficking in the UK or the number of individuals who had been victims of traffickers. The ATMG said that it had collected information on many individuals who had been identified by support organisations but whose cases were not being referred to the system. Primarily, this was because the individuals concerned did not see the benefit of being referred - 'referral' meant that a person's case was being submitted to a central government authority to decide on their status, not that they were being referred to a range of specialised services. A significant number of individuals was therefore being deterred from accessing services and exercising their rights. To this end, the ATMG claimed that the NRM process was 'not fit for purpose' (Anti-Trafficking Monitoring Group, 2010). Concern about this issue was also expressed by GRETA in its report on how well the British authorities had implemented the CoE Convention. GRETA said that the UK should take further steps to ensure that all victims of trafficking were properly identified and could benefit from the protection measures contained in the Convention (Group of Experts on Action Against Trafficking in Human Beings, 2012).

Other possible explanations for the low figures of referral to the NRM were identified by the ATMG in its third report, In the Dock: Examining the UK's Criminal Justice Response to Trafficking; there, the ATMG suggested that human trafficking 
was not sufficiently important to the British police, a key first responder. For instance the ATMG argued that the culture of policing targets meant that the practice was not considered a priority and an investigation was often dependent on the good will and perseverance of individual officers. And many trafficked victims were frequently refused assistance and were told that their problem was not a police matter, especially in instances of labour trafficking. The ATMG therefore warned that the UK Government was at risk of 'losing the fight' against human trafficking unless, for example, the British criminal justice system urgently improved its response to the crime (Anti-Trafficking Monitoring Group, 2013).

Apathy on the part of the police is a view shared by another human rights organisation, the Centre for Social Justice (CSJ), but the CSJ believes the problem is wider, suggesting that many frontline professionals, not just police officers, are illequipped to recognise the practice. The CSJ said they were 'shocked' at the low awareness among other professionals such as immigration, social services etc. An 'appalling outcome of such failure', the CSJ stated, was that numerous victims were being prosecuted for offences they had been compelled to commit as a result of being trafficked (Centre for Social Justice, 2013). The UK’s apparent emphasis on criminalisation is a particular problem. In its first report, the ATMG claimed that the system was paying more attention to, say, the immigration status of a trafficked person rather than the alleged crime committed against them (Anti-Trafficking Monitoring Group, 2010). It reiterated this view in its second report (Anti-Trafficking Monitoring Group, 2012) and indeed in its third report (Anti-Trafficking Monitoring Group, 2013). Concern about this seeming overemphasis in the UK has also been 
expressed by GRETA. It urged the British authorities to step up their efforts to adopt a victim-centred approach, by encouraging prosecutors to consider trafficking as a serious violation of human rights when assessing the public interest of prosecuting identified victims (Group of Experts on Action Against Trafficking in Human Beings, 2012).

Of particular concern about UK efforts to 'protect' victims of trafficking include recent visa changes for employees accompanying their employers to the country, in that the number of women suspected of having been trafficked to perform housework in embassies and private houses has increased by new immigration rules (Peachey, 2013). The old visa system allowed migrant domestic workers to change employers if they were being abused. Indeed, this was recommended as best practice by the ILO (Equality and Human Rights Commission, 2012). But in April 2012, the UK abolished the right of migrant domestic workers to change employer once they were in the country. This change has been criticised by the ATMG in, for example, its second report (Anti-Trafficking Monitoring Group, 2012) and human rights organisations such as Human Rights Watch. The latter says, for example, that workers who are mistreated face a horrendous choice: either endure the terrible abuse, or escape and become undocumented migrants, where they are much more vulnerable to further abuse and exploitation (Human Rights Watch, 2014). These immigration rules have been separately described as 'institutionalised enslavement' (Bowcott \& Laville, 2013). 


\section{Improving the UK’s compliance with its positive, human rights obligations}

In the previous paragraphs shortcomings in the UK's responses to prevent human trafficking such as the NRM were identified. In this section possible solutions to some of these problems will be discussed. It will be recalled that in its third report the ATMG warned that the UK government was at risk of 'losing the fight' against human trafficking unless, for example, the criminal justice system urgently improved its response to the crime. The UK therefore needs to address its apparent overemphasis on, say, the criminalisation of victims. But in the last couple of years or so the British courts have stressed the significance of Article 26 of the CoE Convention to domestic law: Regina v. $M(L)$ [2010] EWCA Crim 2327; Regina v. N, Regina v. L [2012] EWCA Crim 189; and L, HVN, THN v. Regina [2013] EWCA Crim 991. In the latter case, for example, England's Court of Appeal quashed the convictions of three Vietnamese children trafficked into the UK to work in the illegal production of cannabis, since the three were compelled to act because of the control their captors had over them. So the country is seemingly receptive to a trafficked person claiming a defence of duress to a criminal charge as a direct consequence of them being exploited. Nonetheless, the ATMG still believes that the criminal justice process can do more: it suggests that trafficking should be made a police priority and included among targets set by the Home Secretary; and all frontline police officers should receive basic training on trafficking. Guidance should also be available at all police stations to stop the practice of declining assistance to trafficked persons wishing to report the crime (Anti-Trafficking Monitoring Group, 2013). The ATMG also recommends that the government introduce an independent and public review of all negative decisions made by a CA to ensure that no victims of trafficking are 
prosecuted for crimes that they committed while under coercion; this would also ensure the accountability of decision-makers and the quality of decision-making (Anti-Trafficking Monitoring Group, 2010). The ATMG had also noted that a referral by a first responder to a CA was to decide on a person's status, not that they were being referred to a range of specialised services. To this end, the ATMG recommends that the administrative processes of the NRM be restructured and reduced in order to act as a multi-agency identification and referral mechanism, increasing access to services for victims (Anti-Trafficking Monitoring Group, 2010). And in reference to the issue of deportation, the CSJ suggests that the UK Border Agency (the role now undertaken by UKVI) be stripped of its CA status, ensuring that the first decision made about a victim is a welfare one based solely on their need for support. The CSJ claims that too often the UKBA's involvement in the NRM process acts as a major barrier to victims making a referral (Centre for Social Justice, 2013).

It will be recalled that Article 29 of the CoE Convention encourages the establishment of a national rapporteur or equivalent to monitor the implementation of domestic anti-trafficking measures and to advise European governments on trafficking issues. In the UK this role is undertaken by the Inter-Departmental Ministerial Group on Human Trafficking. But the group has not had a positive start. It has met infrequently - in its first 18 months it met on only two occasions - and its attendance has been poor: two thirds of the eligible Ministers gave their apologies (Lipscombe \& Beard, 2014). It is maybe unsurprising, therefore, that there have been calls for a more independent organisation for the UK such as a national rapporteur. The ATMG noted in its first report, for example, that the CoE Convention had 
required a holistic approach to trafficking - that is, 'prevention', 'prosecution' and 'protection' - but a suitable national watchdog for the UK, with the powers to ensure that this had happened, was absent. It believed, therefore, that the creation of a new national anti-trafficking watchdog charged with overseeing the implementation of the whole of the CoE Convention would ensure such an approach was happening (AntiTrafficking Monitoring Group, 2010). Others have argued that a new rapporteur might be more approachable, as non-governmental organisations may be sceptical of a Government-led organisation (Lipscombe \& Beard, 2014). What is required, therefore, is perhaps an 'Anti-Slavery Commissioner' who would be independent of Government. This would offer consistency in the UK's approach, which, the CSJ claims, fluctuates and stalls with changes in government and officials. It would be the single point of contact for the modern slavery agenda and would drive improvements in strategy, awareness, training and information gathering (Centre for Social Justice, 2013).

Another possible explanation for, say, ignorance amongst front line staff such as the police about human trafficking is that there is no unified statute in the UK against modern slavery, often leaving criminal justice actors uncertain about how to identify the crime and prosecute traffickers. The CSJ, for example, has called for a modern Slavery Act for the UK. It says that legislation relating to human trafficking and modern slavery currently lies under several different Acts (see above). This separation is unhelpful, and creates unnecessary confusion for those whose job it is to implement the legislation (Centre for Social Justice, 2013). 


\section{The draft Modern Slavery Bill}

The UK government is now committed to introducing a Slavery Act, which will affect most of the UK, having already published a draft Modern Slavery Bill during the Parliamentary session 2013-14. This draft Bill contained many key features: first, Clause 2 of Part 1 introduced a new human trafficking offence covering both sexual and non sexual exploitation, combining the offences currently found in the Sexual Offences Act 2003 and the Asylum and Immigration (Treatment of Claimants etc.) Act 2004. Clause 5 increased the maximum sentence for human trafficking from 14 years to life imprisonment. The government believed that introducing one offence for all types of trafficking in Clause 2 would make it administratively simpler for investigators and prosecutors to bring forward prosecutions. And these changes would send a very strong signal to the offenders that the UK would not tolerate any form of exploitation and would allow the courts to give stiffer sentences, better reflecting the seriousness of these crimes (Home Office, 2013b).

Part 2 of the draft Bill introduced Slavery and Trafficking Prevention Orders ('STPO’) and Slavery and Trafficking Risk Orders ('STRO'). As per clause 11(1) an STPO could be made in relation to a person who had been convicted of a slavery or human trafficking offence if the prohibitions in the order were considered to be necessary to protect a person from physical or psychological harm, as per clause 11(2). An STPO prohibited the person from doing anything described in the order and 
lasted for a fixed period of at least 5 years, as per clause 14(3); it included prohibitions on foreign travel, as per clause 15. The government argued that the nature of modern slavery including human trafficking was so complex that it required bespoke orders to target effectively the behaviour of individuals and organised criminals (Home Office, 2013b).

Unlike an STPO, an STRO could be imposed on an individual who had not been convicted of an offence. As per clause 21(1) an STRO could made by a court in relation to a person who it considered had acted in a way which made it necessary to protect or person from physical or psychological harm, as per clause 21(3). An STRO prohibited the person from doing anything described in the order and lasted for a fixed period of least 2 years, as per clause 22(3); it included prohibitions on foreign travel, as per clause 23. The conditions imposed by either an STPO or an STRO also included measures such as bans on working with children or employing staff (Home Office, 2013b).

Part 3 of the draft Bill referred to a new Anti-Slavery Commissioner. The government stated that for the first time the country would have a senior figure dedicated to the UK's fight against modern slavery, who would focus on strengthening law enforcement efforts (Home Office, 2013b). As per clause 31(1), the Commissioner had to encourage good practice in the prevention, detection, investigation and prosecution of offences under Part 1; and according to clause 32(1) the Commissioner was obliged to-(a) prepare an annual plan setting out how s/he 
proposed to exercise their functions during the year, and (b) submit the annual plan to the Secretary of State for approval. As per clause 32(2) an annual plan had to, in particular- (a) state the Commissioner's objectives and priorities for the year; (b) state any matters on which s/he proposes to report during the year; and (c) state any other activities s/he proposed to undertake during the year in the exercise of their functions.

Part 4 of the draft Bill introduced a new statutory duty to report potential victims of trafficking. Principally, clause 35(1) provided that a specified public authority must notify the National Crime Agency if it had reasonable grounds to suspect that an individual may have been a victim of human trafficking. What information had to be disclosed would be specified by the Secretary of State, though names and addresses and other identifying information could be withheld if the victim had not consented. So the victims themselves could remain anonymous and would not be obliged to accept support if they did not want it. The purpose of such a legal duty was to ensure that victims could access all the services that were open to them, and that the state would develop an improved picture of the number of victims (Home Office, 2013b). At the same time as the announcement of the draft Bill, the Home Secretary, Theresa May, outlined other non-legislative measures to reduce human trafficking in Britain, such as a review of the operation and effectiveness of the NRM (May, 2013). 


\section{Criticisms of the draft Modern Slavery Bill}

Notwithstanding the government's intention to consolidate the existing human trafficking offences, for example, making the current legislation administratively simpler for investigators and prosecutors, the content of the draft Bill did come in for much criticism, however, particularly from the Parliamentary Committee tasked with reviewing it. In reference to the offences in Part 1 of the draft Bill, the Parliamentary Committee said that these were heavily criticised, with many witnesses describing it as merely a 'cut and paste' of the existing offences, with little thought beyond consolidation. In particular, it did not give adequate consideration to offences committed against children, which many consider to be particularly egregious. The committee also believed that the current definitions within Part 1 were not as broad, clear and simple as the Government had wished them to be, thus they were too confusing as they stood (Parliamentary Joint Committee on the Draft Modern Slavery Bill, 2014).

It will be recalled that Part 2 of the draft Bill introduced Slavery and Trafficking Prevention Orders ('STPOs’) and Slavery and Trafficking Risk Orders ('STROs'). Regarding these, the Parliamentary Committee agreed with the government that they would prevent modern slavery in principle, but disagreed that this was what they would do in practice. In particular reference to STROs, the Committee questioned what types of slavery-related behaviour would fall within the scope of them but would not be a criminal offence; to this end, the committee 
recommended that they be removed (Parliamentary Joint Committee on the Draft Modern Slavery Bill, 2014).

Part 3 of the Bill created the office of a new Anti-Slavery Commissioner. The Parliamentary Committee welcomed the proposal but believed that the statutory safeguards intended to ensure independence were not satisfactory. Part 4 also introduced a new statutory duty to report potential victims of trafficking. In response, the Committee recommended that this also be removed from the draft Bill. While it very much supported the Government's desire to improve statistics on modern slavery, it was not clear that imposing a duty on NRM first responders to notify the National Crime Agency to potential victims of human trafficking would achieve that aim. At the same time, it risked undermining trust in, and use of, vital victim services (Parliamentary Joint Committee on the Draft Modern Slavery Bill, 2014).

The draft Bill was also criticised not only for what it had included, but also for what it had excluded. In reference to the principle of non-criminalisation of victims, such as that recommended in Article 26 of the CoE Convention, the Parliamentary Committee believed that there should be a statutory defence of being a victim of modern slavery (Parliamentary Joint Committee on the Draft Modern Slavery Bill, 2014). And the draft Bill could have done more for trafficked children. Charities say that trafficked children are usually alone in the UK with no one who has parental responsibility for them; they face complex and terrifying systems of welfare, immigration and law enforcement with no one to guide them through (Dugan, 2013a). 
There have therefore been calls for the appointment of guardians for those children suspected of having been trafficked (indeed, this was a recommendation in Article 23 of the EU Directive). A system of guardianship would mean that every child victim of trafficking would have a legal guardian with parental responsibility, providing care and support and ensuring that they receive the educational, medical, practical and legal support they need (ECPAT UK, 2014).

The draft Bill also made no reference to the recent immigration changes to the Overseas Domestic Worker Visa; the Parliamentary Committee recommended reversing these reforms. Similar to earlier claims by the CSJ, for example, that the UKVI be stripped of its CA status, the Committee noted, too, that the draft Bill had been a missed opportunity to remove those with responsibility for determining immigration claims from making decisions on human trafficking (Parliamentary Joint Committee on the Draft Modern Slavery Bill, 2014).

\section{The Modern Slavery Bill 2014-15}

Following consultations on the draft Bill a revised Modern Slavery Bill was introduced by the government in Parliament for legislative approval in June 2014. The government fanfare accompanying it mirrored that of the publication of its draft Bill (Gov.UK, 2014a). Despite the many changes to the draft Bill recommended by the Parliamentary Committee, the revised Bill is largely the same as the previous version: Part 1 still consolidates the existing trafficking offences and increases the maximum 
sentences from 14 years to life imprisonment; Part 2 still introduces Slavery and Trafficking Prevention Orders (STPOs) and Slavery and Trafficking Risk Orders (STROs); Part 4 (though it was Part 3 in the original Bill) still creates a new AntiSlavery Commissioner; and Part 5 (though it was Part 4 in the original Bill) still imposes a statutory duty on public authorities to notify the National Crime Agency about potential victims of modern slavery.

It will be recalled that the Parliamentary Committee reviewing the draft Bill had raised concerns about the offences in Part 1, such as a lack of offences where children were the victims. In its defence, the UK government said that such a move could result in six different offences relating to each victim being considered at trial which risked causing confusion for juries and making convictions more difficult (Home Office, 2014). The Parliamentary Committee had also raised concerns about whether STPOs and STROs would be an effective preventative measure in practice, and in particular recommended that STROs be removed. Again, in its defence, the UK government said that after careful consideration, and further consultation with law enforcement bodies, it had concluded that STPOs and STROs were still necessary to prevent modern slavery (Home Office, 2014). In particular, it said that STROs mirror similar non-conviction orders for other harmful activity (for example - sexual harm), and they enable action to be taken where this was necessary to prevent serious harm to the public notwithstanding the absence of a conviction (Home Office, 2014). The Parliamentary Committee had also expressed doubt about the independence of the Anti-Slavery Commissioner, suggesting, for example, the removal of the Secretary of State's approval for the priorities in the Commissioner's strategic plan. Again, in its defence, the government said that it was normal for an independent Commissioner to 
agree his or her programme with the Secretary of State. It was critical that the Commissioner and the Secretary of State build a partnership, where the Commissioner's work helps the Secretary of State to push through real change to stamp out modern slavery. The requirement for approval helped ensure this coherence (Home Office, 2014).

There are some additions in the current Bill, however: clause 8 gives the courts new powers to order perpetrators of slavery and trafficking to pay Reparation Orders to their victims; and clause 45 creates a new statutory defence for victims where they have been compelled to commit a criminal act as a result of their slavery or trafficking experience (though this provision has been criticised by, say, the UK's Equality and Human Rights Commission for being 'overly complex for consideration by a jury’ (Equality and Human Rights Commission, 2014).)

To comply with Article 23 of the EU Directive, Clause 48 also provides an enabling power for the creation of guardians, or 'advocates', to protect, support and guide child victims of trafficking through the immigration, criminal justice and care systems. This scheme will be tested in two six-month Home Office trials, it has been announced (Gov.UK, 2014a). But the proposals in clause 48, as originally stated, stopped short of a system of legal guardianship, granting powers to advocates equivalent to those of a parent. However, at the time of writing it has been reported that the UK government is willing to grant advocates of child victims legal powers. It is claimed that co-ordinated and timely action on the part of public agencies is more likely to occur if such guardians are granted such powers (ECPAT UK, 2015). 
Moreover, since the original publication of the current Bill, the government has announced a further provision, which is now clause 52, 'transparency in supply chains'. This will require big businesses to publicly state each year what action they have taken to ensure their supply chains are exploitation free: 'a slavery and human trafficking statement'. The government claims that the measures go further than any similar legislation in the world by applying to businesses regardless of the nature of a company or what it supplies. There are similar requirements in California but the government argues that they only apply to businesses producing goods for sale. These measures will apply regardless of the nature of the company or what it supplies, whether goods or services (Gov.UK, 2014d). The breadth of this provision is currently subject to public consultation (Gov.UK, 2015a).

At the same time as the UK government's publication of its draft Slavery Bill, it may be recalled that the Home Secretary, Theresa May, had also pledged to commission a review of the NRM (May, 2013), which the government published in November 2014 (Home Office, 2014b). This review found, for example, that the NRM system was 'disjointed' and awareness of its processes was often very low. The review's recommendations included: increased awareness of human trafficking by the public and professionals, as well as improved data collection, to improve victim identification; and a new process of conclusive identification of victims through regional panels, with a view to ceasing the sole decision-making roles of the UKVI and UKHTC. 


\section{Preventing human trafficking in comparable Western European countries}

There is little doubt that the UK is committed to preventing human trafficking, as per its positive human rights obligations, especially with the reforms to be introduced by the Modern Slavery Bill. But how does the country compare in its prevention attempts with similar countries to it in Western Europe, such as Belgium, France, Germany, Holland and Ireland? At a very basic level it is said that all of these countries, including the UK, fully comply with the minimum standards for the elimination of human trafficking (US Department of State, 2014). In specific reference to Belgium, for example, GRETA notes the efforts made by the Belgian authorities to, say, apply a multidisciplinary approach to the identification and referral of victims, though shortcomings in the identification process still persist. In particular, GRETA urges the authorities to take additional measures for the detection and referral of child victims. And in some cases, owing to a lack of knowledge of the referral mechanism, victims in Belgium are not granted a recovery and reflection period (Group of Experts on Action Against Human Trafficking, 2013a). On the positive side, Belgium carries a maximum sentence of 20 years imprisonment for human trafficking, and, like the UK, has a 45 day recovery and reflection period; the country also possesses a national rapporteur providing independent, self-critical analysis of the state’s efforts to fight trafficking (US Department of State, 2014).

Whilst France has outlawed human trafficking since 2003, unlike the UK, this offence concentrates on exploitation for sexual purposes, ignoring, say, labour 
exploitation. France also lacks a statistical system collecting data on victims of human trafficking, thus GRETA says it is difficult to have a reliable picture of the national situation there, enabling the country to take the most effective measures against trafficking. Furthermore, many victims in France are accommodated in nonspecialised shelters; and the 30 day reflection period for victims appears to focus on their decision to co-operate with the authorities without taking into account their need to recover (Group of Experts on Action Against Human Trafficking, 2013b). On the plus side, the maximum sentence for trafficking in France is 30 years imprisonment. But the country lacks a national rapporteur; and the reflection period is not known to some state authorities so support is not offered to many victims (US Department of State, 2014).

Holland first criminalised trafficking in some form in 1911 - 'white traffic' and has had a national rapporteur since 2000. The Dutch authorities have 'taken decisive steps to develop the legal and institutional framework for action against trafficking; and they have developed an approach based on multi-agency cooperation and action to combat trafficking at national and local levels. But the country's identification process is in the sole hands of law enforcement agencies. GRETA therefore urges the authorities to strengthen multi-agency involvement in the decision-making process leading to victim identification (Group of Experts on Action Against Trafficking in Human Beings, 2014). The recovery and reflection period in Holland is far longer than that in the UK - three months, compared to 45 days though there are some concerns that the authorities there place too much emphasis in this period on the victim's participation in criminal proceedings against their abusers, 
rather than allowing them time to recover. The maximum sentence for trafficking in Holland is life imprisonment (US Department of State, 2014).

GRETA is yet to publish a report on Germany's compliance with the CoE Convention, but information about its attempts to prevent human trafficking is still available. Germany has outlawed trafficking in some form since 1973; and the maximum sentence there is 10 years imprisonment. The country also offers a much longer recovery and reflection period than the UK: three months. But a large number of offenders are given only suspended sentences creating potential safety problems for victims and weakening deterrence. And addressing labour trafficking 'continues to be a significant weakness in the government's response'. Section 233 of Germany's penal code, the prohibition on labour trafficking, carries a high burden of proof, thus several offenders escape justice and victims are denied protection. Germany is also advised to create a national rapporteur (US Department of State, 2014). Ireland has a maximum sentence of life imprisonment for human trafficking. Like the UK, it, too, exceeds the 30 day minimum recovery and reflection period, but is longer than the UK: 60 days, compared to the UK's 45. Ireland is advised to do more to comply with, say, Article 26 of the CoE Convention (Group of Experts on Action Against Human Trafficking, 2013c) and establish a national rapporteur (US Department of State, 2014). 


\section{Conclusion}

A contemporary form of slavery is human trafficking. International and regional efforts to prevent trafficking have included the UN Protocol, the CoE Convention and the EU Directive. The UK has ratified all of these. Freedom from slavery, including trafficking, much like other human rights, acts 'negatively', in that states desist from interfering with the right, representing traditional liberal notions of freedom of the individual. But the right also acts 'positively' in that states must take substantive measures to prevent a violation of the right by third parties. This obligation can be discharged in several ways such as the prosecution of offenders and the protection of victims, as well as fulfilling a secondary duty to investigate alleged infringements.

A modern Slavery Act for the UK is now close to being a reality. Arguably, it will strengthen the country's 'prosecute' (or now 'pursue') obligations, since it will substantially increase the maximum sentences for human trafficking and ought to simplify the law for police and prosecutors (though critics claim that the simplification of the law is merely a 'cut and paste' job of existing offences, ignoring, say, the demands for separate offences aimed at protecting child victims). And there will be a new statutory defence to victims of trafficking compelled to commit criminal acts as a consequence of their exploitation, as per Article 26 of the CoE Convention, which will reinforce the UK's 'protect' responsibilities (though this defence is not without its critics, too, because of its apparent complexity). 'Protect' will be further 
enhanced by the establishment of advocates for child victims, as per Article 23 of the EU Directive, especially if they will be granted legal powers, as promised.

Much of this article has been concerned with an evaluation of the NRM. The 45 day review and reflection period is longer than the minimum of 30 days suggested in the CoE Convention. But what is particularly evident from this assessment is that the NRM is seemingly failing potential victims of trafficking because, say, the 'dark figure' for modern slavery is significantly higher than the numbers of victims being referred by first responders to the country's two CAs, the UKHTC and UKVI. The reasons for this include: low awareness of human trafficking amongst professionals; the referral process is often seen more as an assessment exercise by the state rather than as a way of granting victims access to support services; and victims fear referral to stage agencies may result in their criminalisation and/or deportation. To this end, there is a convincing argument supporting, for example, an independent and public review of all negative decisions by the CAs, as well as the removal of CA status from, say, the UKVI. That said, the government has recently published a review of the NRM where it pledges to remove the monopoly of the UKVI, as well as the UKHTC, over the process of considering victims. This is, therefore, an opportunity to further strengthen Britain's commitment to 'protect' those that have been trafficked.

Article 29 of the CoE Convention encourages the creation of a national rapporteur for human trafficking. The current Bill establishes an Anti-Slavery Commissioner which ought to reinforce the UK's 'prevent' obligations (though doubt 
remains about the independence of this role). 'Prevent' should also be enhanced by, say, the imposition of yearly duties on large companies to state what action they have taken to ensure their supply chains are free from exploitation, as well as the introduction of STPOs and STROs.

The UK's existing anti-trafficking measures suggest that the country's approach to honouring its human rights obligations is patchy. The government has introduced a Modern Slavery Bill 2014-15 which it describes as ‘world leading’. This is a grand claim. But the government's commitments in the Bill, together with efforts to address concerns in its review of the NRM, suggest great strides will be made in fulfilling its positive duties. Whilst some doubts remain about the effectiveness of some of the measures to be introduced, as well as the failure to reverse the 2012 visa changes to the domestic worker scheme, the proposals for reform are still significant, especially when compared to, say, anti-trafficking initiatives in comparable Western European countries such as France and Germany. Germany, for example, has a maximum sentence for trafficking of only 10 years and lacks a national rapporteur. In addition, too many convicted offenders are given suspended sentences there, thus, compromising the safety of victims and increasing the risk of them being retrafficked. On paper, Holland is maybe a model for other states to follow in adopting measures to combat human trafficking (though it, too, is not without its own critics) but the UK is certainly trying to catch up with - if not surpass - countries like Holland with its own legislative reforms. 


\section{References}

Anti-Trafficking Monitoring Group (2010). Wrong kind of victim? One year on: an analysis of UK measures to protect trafficked persons. June http://www.antislavery.org/includes/documents/cm_docs/2010/a/1_atmg_report_for_ web.pdf (Accessed July 6 ${ }^{\text {th }}$ 2013).

Anti-Trafficking Monitoring Group (2012). All change: preventing trafficking in the UK. June http://s111999.gridserver.com/wp-content/uploads/2012/05/AntiTrafficking-Monitoring-Group-report-2012-All-Change-Prevention-low-res.pdf (Accessed July $8^{\text {th }}$ 2013).

Anti-Trafficking Monitoring Group (2013). In the dock: examining the UK’s criminal justice response to trafficking. June http://www.antislavery.org/includes/documents/cm_docs/2013/i/inthedock_final_smal l_file.pdf (Accessed November 10 ${ }^{\text {th }}$ 2013).

Booth, R. (2014). Child trafficking victims to be given personal advocates in Home Office trial. The Guardian. January $26^{\text {th }}$ http://www.theguardian.com/society/2014/jan/26/child-trafficking-victims-personaladvocates-home-office-trial (Accessed February 25 ${ }^{\text {th }}$ 2014).

Bowcott, O. and Laville, S. (2013). Modern Slavery Bill set to streamline human trafficking cases. The Guardian. November $22^{\text {nd }}$ http://www.theguardian.com/world/2013/nov/22/modern-slavery-bill-humantrafficking (Accessed February $21^{\text {st }}$ 2014).

Brayley, H. and Cockbain, E. (2014) British children can be trafficked too: towards an inclusive definition of internal child sex trafficking. Child Abuse Review, 23, 171184.

Centre for Social Justice (2013). It happens here: equipping the United Kingdom to fight modern slavery. March.

http://www.centreforsocialjustice.org.uk/UserStorage/pdf/Pdf\%20reports/CSJ_Slaver y_Full_Report_WEB(5).pdf (Accessed July $9^{\text {th }}$ 2013). 
Chaudary, A. (2011). Victim status under the Council of Europe Convention on Action Against Trafficking in Human Beings: the situation of 'historical' victims. Journal of Immigration, Asylum and Nationality Law, 25, 168-178.

Datta, M. and Bales, K. (2013). Slavery in Europe: part 1, estimating the dark figure. Human Rights Quarterly, 35(4), 817-829.

Doward, J. (2012). People smugglers target their victims as organ donors and house slaves. The Guardian. August $26^{\text {th }}$ http://www.theguardian.com/law/2012/aug/26/people-smugglers-organ-donors (Accessed March $3^{\text {rd } 2014) .}$

Drew, S. (2002). Human trafficking: a modern form of slavery? European Human Rights Law Review, 4, 489-507.

Drew, S. (2009). Human trafficking - human rights: law and practice. Legal Action Group.

Dugan, E. (2013a). Government failing to bring Britain in line with European rules on human trafficking, say charities. The Independent. March $10^{\text {th }}$ http://www.independent.co.uk/news/uk/home-news/government-failing-to-bringbritain-in-line-with-european-rules-on-human-trafficking-say-charities-8528099.html (Accessed March 12 ${ }^{\text {th }}$ 2014).

Dugan, E. (2013b). UK is warned it is losing fight against modern slavery. The Independent. June $11^{\text {th }}$ http://www.independent.co.uk/news/uk/crime/exclusive-uk-iswarned-it-is-losing-fight-against-modern-slavery-8654529.html (Accessed July $8^{\text {th }}$ 2013).

ECPAT UK (2014). Guardianship for child victims of trafficking campaign. http://www.ecpat.org.uk/campaigns/guardianship (Accessed June 10 ${ }^{\text {th }} 2014$ ).

ECPAT UK (2015). Historic campaign win secures extra support for trafficked children. February $25^{\text {th }}$ http://www.ecpat.org.uk/media/historic-campaign-winsecures-extra-support-trafficked-children (Accessed March 2nd 2015). 
Equality and Human Rights Commission (2013). Human rights review 2012: Article 4: freedom from slavery and forced labour.

http://www.equalityhumanrights.com/uploaded_files/humanrights/hrr_article_4.pdf (Accessed June 12 ${ }^{\text {th }}$ 2013).

Equality and Human Rights Commission (2014). Modern Slavery Bill 2014: House of Lords, Second Reading. November $17^{\text {th }}$ http://www.equalityhumanrights.com/legaland-policy/our-legal-work/parliamentary-briefings/modern-slavery-bill-house-lordssecond-reading (Accessed February 22nd 2015).

Gallagher, A. (2014) The trafficking watchlist may be flawed, but it’s the best measure we have. The Guardian. June $27^{\text {th }}$ http://www.theguardian.com/globaldevelopment/poverty-matters/2014/jun/27/human-trafficking-watchlist-report (Accessed November 17 ${ }^{\text {th }}$ 2014).

Gov.UK (2014a). Modern Slavery Bill published. June $10^{\text {th }}$ https://www.gov.uk/government/news/modern-slavery-bill-published (Accessed June

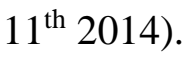

Gov.UK (2014b). Big business to be held to account to keep supply chains slavery free. October $13^{\text {th }}$ https://www.gov.uk/government/news/big-business-to-be-held-toaccount-to-keep-supply-chains-slavery-free (accessed November $4^{\text {th }} 2014$ ).

Gov.UK (2015a). Government action to tackle slavery in supply chains. February $12^{\text {th }}$ https://www.gov.uk/government/news/government-action-to-tackle-slavery-insupply-chains (accessed February 25th 2015).

Gov.UK (2015b). Modern Slavery Bill strengthened to provide better protection for victims. February $17^{\text {th }}$ https://www.gov.uk/government/news/modern-slavery-billstrengthened-to-provide-better-protection-for-victims (accessed February 25th 2015).

Group of Experts on Action Against Trafficking in Human Beings (2012). Report concerning the implementation of the Council of Europe Convention on Action against Trafficking in Human Beings by the United Kingdom. September http://www.coe.int/t/dghl/monitoring/trafficking/docs/Reports/GRETA_2012_6_FGR _GBR_en.pdf (Accessed June 13th 2014). 
Group of Experts on Action Against Trafficking in Human Beings (2013a). Report concerning the implementation of the Council of Europe Convention on Action against Trafficking in Human Beings by Belgium. September http://www.coe.int/t/dghl/monitoring/trafficking/docs/Reports/GRETA_2013_14_FG

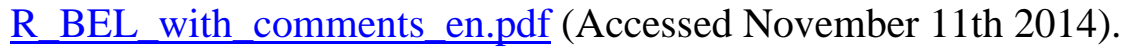

Group of Experts on Action Against Trafficking in Human Beings (2013b). Report concerning the implementation of the Council of Europe Convention on Action against Trafficking in Human Beings by France. January http://www.coe.int/t/dghl/monitoring/trafficking/docs/Reports/GRETA_2012_16_FG R_FRA_publication_en.pdf (Accessed November 11th 2014).

Group of Experts on Action Against Trafficking in Human Beings (2013c). Report concerning the implementation of the Council of Europe Convention on Action against Trafficking in Human Beings by Ireland. September http://www.coe.int/t/dghl/monitoring/trafficking/docs/Reports/GRETA_2013_15_FG R_IRL_public_en.pdf (Accessed November 11th 2014).

Group of Experts on Action Against Trafficking in Human Beings (2014). Report concerning the implementation of the Council of Europe Convention on Action against Trafficking in Human Beings by the Netherlands. June http://www.coe.int/t/dghl/monitoring/trafficking/docs/Reports/GRETA_2013_15_FG $\underline{\text { R_IRL_public_en.pdf (Accessed November 12 }}{ }^{\text {th }} 2014$ ).

HM Government (2011). Human trafficking: the Government’s strategy. July https://www.gov.uk/government/uploads/system/uploads/attachment_data/file/97845/ human-trafficking-strategy.pdf (Accessed June 13th 2014).

HM Government (2012). First annual report of the Inter-Departmental Ministerial Group on Human Trafficking. October. Cm 8421. https://www.gov.uk/government/uploads/system/uploads/attachment_data/file/118116 /human-trafficking-report.pdf (Accessed February 21st 2014). 
HM Government (2013). Second annual report of the Inter-Departmental Ministerial Group on Human Trafficking. October. Cm 8731.

https://www.gov.uk/government/uploads/system/uploads/attachment_data/file/251487 /9794-TSO-HMG_Human_Trafficking.pdf (Accessed January 22nd 2014).

HM Government (2014a). Joint statement of the Inter-Departmental Ministerial Group (IDMG) on modern slavery. October $18^{\text {th }}$

https://www.gov.uk/government/uploads/system/uploads/attachment_data/file/364860 /IDMG_statement_v5_WEB.PDF (Accessed November $4^{\text {th }} 2014$ ).

HM Government (2014b). Modern Slavery Strategy.

https://www.gov.uk/government/uploads/system/uploads/attachment_data/file/383764 /Modern_Slavery_Strategy_FINAL_DEC2015.pdf (Accessed February 13th 2015).

Home Office (2013a). Home Secretary speech on modern slavery. December $4^{\text {th }}$ https://www.gov.uk/government/speeches/home-secretary-speech-on-modern-slavery (Accessed February 21st 2014).

Home Office (2013b). Draft Modern Slavery Bill. December. CM 8770 https://www.gov.uk/government/uploads/system/uploads/attachment_data/file/266165 /Draft_Modern_Slavery_Bill.pdf (Accessed June $9^{\text {th }}$ 2014).

Home Office (2014a). Draft Modern Slavery Bill: the Government response to the report from the Joint Committee on the Draft Modern Slavery Bill Session 2013-14 HL Paper 166 / HC 1019. Cm 8889. June https://www.gov.uk/government/uploads/system/uploads/attachment_data/file/318771 /CM8889DraftModernSlaveryBill.pdf (Accessed July 8th 2014).

Home Office (2014b). Review of the national referral mechanism for victims of human trafficking. November 2014 http://socialwelfare.bl.uk/subject-areas/servicesclient-groups/asylum-seekersrefugees/homeoffice/168761Review_of_the_National_Referral_Mechanism_for_victi ms_of_human_trafficking.pdf (Accessed February 16th 2015). 
Human Rights Watch (2014). Hidden away: abuses against migrant domestic Workers in the UK. March 31 $1^{\text {st }}$. http://www.hrw.org/reports/2014/03/31/hidden-away-0 (Accessed May 2nd 2014).

International Labour Organisation (2012). Global estimate of forced labour: results and methodology. http://www.ilo.org/wcmsp5/groups/public/---ed_norm/--declaration/documents/publication/wcms_182004.pdf (Accessed July 4th 2012).

Lee, M. (2007). Introduction: understanding human trafficking. In Lee, M. (ed). (2007). Human trafficking. Willan Publishing, 1-25.

Lipscombe, S. and Beard, J. (2014). Human Trafficking: UK Responses. January $13^{\text {th }}$. SN/HA/1324. http://www.parliament.uk/business/publications/research/briefingpapers/SN04324/human-trafficking-uk-responses (Accessed March 20th 2014).

Mattar, M. (2008). Comparative models of reporting mechanisms on the status of trafficking in human beings. Vanderbilt Journal of Transnational Law, 41, 1355-1415.

May, T (2103). Home Secretary foreword to Draft Modern Slavery Bill. December. CM 8770/

https://www.gov.uk/government/uploads/system/uploads/attachment_data/file/266165 /Draft_Modern_Slavery_Bill.pdf (Accessed June 9th 2014).

McCrudden, C. (2011). Slavery and the constitutional role of judges. November $2^{\text {nd }}$. http://ukconstitutionallaw.org/2011/11/02/christopher-mccrudden-slavery-and-theconstitutional-role-of-judges/ (Accessed November $29^{\text {th }} 2014$ ).

Milmo, C. (2013). Beaten and brainwashed: story of the three South London women held as slaves - and there may be 6,000 others across Britain. The Independent. November $23^{\text {rd }}$ http://www.independent.co.uk/news/uk/crime/beaten-andbrainwashed-story-of-the-women-held-as-slaves--and-there-may-be-6000-othersacross-britain-8958198.html (Accessed February 25th 2014).

National Crime Agency (2012). About the NCA. http://www.soca.gov.uk/aboutsoca/about-the-ukhtc/an-overview-of-human-trafficking (Accessed July 10th 2012). 
National Crime Agency (2014). National referral mechanism.

http://www.nationalcrimeagency.gov.uk/about-us/what-we-do/specialistcapabilities/uk-human-trafficking-centre/national-referral-mechanism (Accessed

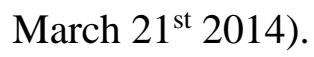

National Crime Agency (2015). National referral mechanism statistics - end of year summary 2014. http://www.nationalcrimeagency.gov.uk/publications/nationalreferral-mechanism-statistics/502-national-referral-mechanism-statistics-end-of-yearsummary-2014 (Accessed February 25th 2015).

Obokata, T. (2006). Trafficking of human beings from a human rights perspective: towards a holistic approach. Martinus Nijhoff Publishers.

Parliamentary Joint Committee on Human Rights (2006). Human trafficking. Twenty-Sixth Report of Session 2005-06 . October $9^{\text {th }}$ http://www.publications.parliament.uk/pa/jt200506/jtselect/jtrights/245/245.pdf (Accessed January $9^{\text {th }}$ 2013).

Parliamentary Joint Committee on Human Rights (2014). Legislative scrutiny: (1) Modern Slavery Bill and (2) Social Action, Responsibility and Heroism Bill. Third Report of Session 2014-15. November $5^{\text {th }}$ http://www.publications.parliament.uk/pa/jt201415/jtselect/jtrights/62/6202.htm (Accessed November 13th 2014).

Parliamentary Joint Committee on the Draft Modern Slavery Bill (2014). Draft Modern Slavery Bill. Report of Session 2013-14 HC 1019. April.

http://www.publications.parliament.uk/pa/jt201314/jtselect/jtslavery/166/166.pdf (accessed June 10 ${ }^{\text {th }}$ 2014).

Pati, R. (2011). States’ positive obligations with respect to human trafficking: the European Court of Human Rights breaks new ground in Rantsev v. Cyprus \& Russia, Boston University international law journal, 29, 79-142. 
Peachey, P. (2013). More women forced into slavery after change to immigration law. The Independent. February $3^{\text {rd }}$ http://www.independent.co.uk/news/uk/crime/morewomen-forced-into-slavery-after-change-to-immigration-law-8478998.html (Accessed February 21 2014 ).

Piotrowicz, R. (2012). States' obligations under human rights law towards victims of trafficking in human beings. International Journal of Refugee Law, 24(2), 181-201.

Press Association (2014). Couple in court on slavery charge. The Guardian. March $7^{\text {th }}$ http://www.theguardian.com/world/2014/mar/07/couple-court-slavery-charge (Accessed March $8^{\text {th }}$ 2014).

Scarpa, S. (2008). Trafficking in human Beings: modern slavery. Oxford University Press.

Stoyanova, V. (2012). Dancing on the borders of Article 4: human trafficking and the European Court of Human Rights in the Rantsev Case. Netherlands Quarterly of Human Rights, 30(2), 163-194.

Stoyanova, V. (2014). Article 4 of the ECHR and the obligation of criminalising slavery, servitude, forced labour and human trafficking. Cambridge Journal of International and Comparative Law, 3(2), 1-37.

Turner, I. (2014). Positive obligations and Article 4 of the European Convention on Human Rights: a defence of the UK's Human Rights Act 1998. International Journal of Human Rights, 18(1), 94-114.

UK Human Trafficking Centre (2013). A strategic assessment on the nature and scale of human trafficking in 2012. August http://www.ecpat.org.uk/sites/default/files/ext6538_ukhtc_strategic_assesssment_on_human_trafficking_2012_v1.01.pdf (Accessed

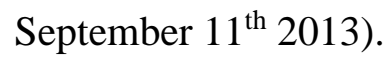

US Department of State (2014). Trafficking in Persons Report 2014. http://www.state.gov/j/tip/rls/tiprpt/2014/?utm_source=NEW+RESOURCE:+Traffick $\underline{\text { ing }+ \text { in }+ \text { Persons }+R}$ (Accessed November $11^{\text {th }} 2014$ ). 
Walk Free Foundation (2014). Global slavery index 2014. November $17^{\text {th }}$ http://d3mj66ag90b5fy.cloudfront.net/wpcontent/uploads/2014/11/Global_Slavery_Index_2014_final_lowres.pdf (Accessed November $\left.19^{\text {th }} 2014\right)$.

van der Wilt, H. (2014). Trafficking in human beings, enslavement, crimes against humanity: unravelling the concepts. Chinese Journal of International Law, 13(2), 297334.

Young, A. (2014). Horizontality and the EU Charter. January $29^{\text {th }}$ http://ukconstitutionallaw.org/2014/01/29/alison-young-horizontality-and-the-eucharter/ (Accessed November 19 $9^{\text {th }} 2014$ ). 